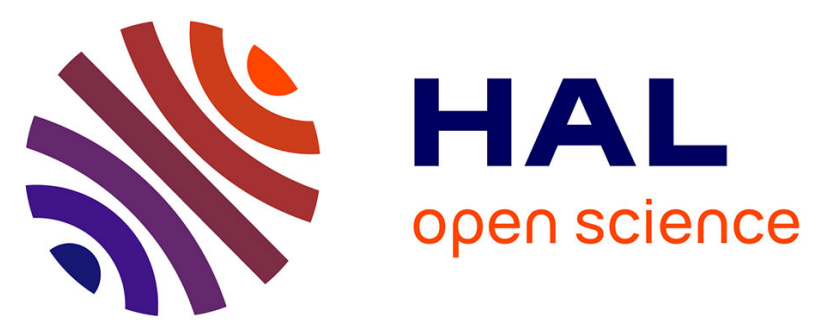

\title{
Electron Paramagnetic Resonance Study of a Photosynthetic Microbial Mat and Comparison with Archean Cherts
}

Mathilde Bourbin, Sylvie Derenne, Didier Gourier, Jean-Noël Rouzaud, Pascale Gautret, Francès Westall

\section{To cite this version:}

Mathilde Bourbin, Sylvie Derenne, Didier Gourier, Jean-Noël Rouzaud, Pascale Gautret, et al.. Electron Paramagnetic Resonance Study of a Photosynthetic Microbial Mat and Comparison with Archean Cherts. Origins of Life and Evolution of Biospheres, 2012, 42 (6), pp.569-585. 10.1007/s11084-0129320-3 . insu-00767794

\section{HAL Id: insu-00767794 https://hal-insu.archives-ouvertes.fr/insu-00767794}

Submitted on 5 Feb 2013

HAL is a multi-disciplinary open access archive for the deposit and dissemination of scientific research documents, whether they are published or not. The documents may come from teaching and research institutions in France or abroad, or from public or private research centers.
L'archive ouverte pluridisciplinaire HAL, est destinée au dépôt et à la diffusion de documents scientifiques de niveau recherche, publiés ou non, émanant des établissements d'enseignement et de recherche français ou étrangers, des laboratoires publics ou privés. 


\title{
Electron Paramagnetic Resonance Study of a Photosynthetic Microbial Mat and Comparison with Archean Cherts
}

\author{
M. Bourbin ${ }^{1}$, S. Derenne ${ }^{1}$, D. Gourier ${ }^{2}$, J.-N. Rouzaud ${ }^{3}$, P. Gautret ${ }^{4}$ and F. Westall $^{5}$ \\ Biogéochimie et Ecologie des Milieux Continentaux, UMR CNRS 7618, Université Pierre et \\ Marie Curie, 4 place Jussieu, 75252 Paris Cedex 05, France
}

Chimie-ParisTech, Laboratoire de Chimie de la Matière Condensée de Paris, UMR CNRS 7574, 11 rue Pierre et Marie Curie, 75005 Paris, France

Laboratoire de Géologie de l'Ecole Normale Supérieure, UMR CNRS 8538, 24 rue Lhomond, 75231 Paris Cedex 05, France

Université d'Orléans, ISTO, UMR CNRS 7327, 45071 Orléans, France

Centre de Biophysique Moléculaire, UPR CNRS 4301, rue Charles Sadron, 45071 Orléans

Cedex 02, France

\begin{abstract}
Organic radicals in artificially carbonized biomass dominated by oxygenic and non-oxygenic photosynthetic bacteria, Microcoleus chthonoplastes-like and Chloroflexus-like bacteria respectively, were studied by Electron Paramagnetic Resonance (EPR) spectroscopy. The two bacteria species were sampled in mats from a hypersaline lake. They underwent accelerated ageing by cumulative thermal treatments to induce progressive carbonization of the biological material, mimicking the natural maturation of carbonaceous material of Archean age. For thermal treatments at temperatures higher than $620^{\circ} \mathrm{C}$, a drastic increase in the EPR linewidth is observed in the carbonaceous matter from oxygenic photosynthetic bacteria and not anoxygenic photosynthetic bacteria. This selective EPR linewidth broadening reflects the presence of a catalytic element inducing formation of radical aggregates, without affecting the molecular structure or the microstructure of the organic matter, as shown by Raman spectroscopy and Transmission Electron Microscopy. For comparison, we carried out an EPR study of organic radicals in silicified carbonaceous rocks (cherts) from various localities, of different ages ( 0.42 to $3.5 \mathrm{Gyr}$ ) and having undergone various degrees of metamorphism, i.e. various degrees of natural carbonization. EPR linewidth dispersion for the most primitive samples was quite significant, pointing to a selective dipolar broadening similar to that observed for carbonized bacteria. This surprising result merits further evaluation in the light of its potential use as a marker of past bacterial metabolisms, in particular oxygenic photosynthesis, in Archean cherts.
\end{abstract}

\section{Keywords}

Archean Electron Paramagnetic Resonance Accelerated ageing Carbonaceous matter Chert 


\section{Introduction}

The earliest traces of Life occur in rocks dating from 3.5 to 3.2 Gyr ago (Westall et al. 2006a, $b$; Ueno et al. 2008; Derenne et al. 2008; Shen et al. 2009; Javaux et al. 2010; Westall 2011). In the Archean Eon (3.8 - 2.5 Gyr ago), the early atmosphere contained a very low concentration of $\mathrm{O}_{2}$ with estimates ranging from $0.001 \%$ (Kump 2008) to $2 \%$ (Towe 1996) of its present value. This period was followed by a drastic increase in $\mathrm{O}_{2}$ in the atmosphere between about 2.3 to $2.4 \mathrm{Gyr}$ ago (Holland 1984; 1999; Barley et al. 2005).

The origins of this so-called Great Oxidation Event (GOE) are debated: photolysis of water vapour with subsequent loss of hydrogen to space, changes in the redox state and the influence of volcanic gas output (Kasting et al. 1993; Holland 2002; Gaillard et al. 2011), or short to long-term consequences of the appearance of oxygenic photosynthesis (Kopp et al. 2005; Catling and Claire 2005)? Studies of rocks 3.2 to 3.5 Gyr old document the probable existence of anoxygenic photosynthesis (Perry et al. 1971; Tice and Lowe 2004; Kappler et al. 2005; Konhauser et al. 2005; Olson 2006; Westall et al. 2006a; Bosak et al. 2007; Croal et al. 2009; Westall 2011; Westall et al. 2011), but the exact timing of the appearance of oxygenic photosynthesis is highly debated. There are three main schools of thought (Buick 2008):

(i) Oxygenic photosynthesis appeared very early on Earth and the Archean atmosphere always showed high $\mathrm{O}_{2}$ rates (Ohmoto 1997; Ohmoto et al. 2006). Note that Ohmoto (Ohmoto et al. 2008) now suggests the presence of oxygen oases, rather than a totally oxidized atmosphere.

(ii) Oxygenic photosynthesis appeared long before the GOE, but it took hundreds of millions of years to fill all near-surface oxygen sinks (Catling and Claire 2005).

(iii) Oxygenic photosynthesis arose shortly before the GOE, causing major environmental and atmospheric changes (Kopp et al. 2005).

Hypothesis (i) is highly controversial and the evidence for early oxygenic photosynthesis is conflicting. On the one hand, the presence of detrital pyrite in paleosoils and mass independent sulfur isotopes indicate an anoxic Archean atmosphere prior to the GOE (Rye and Holland 1998; Rasmussen and Buick 1999; Farquhar et al. 2000; Pavlov and Kasting 2002), whereas, on the other hand, Schopf et al. (1983), Hofmann et al. (1999) and Schopf (2011) hypothesise the existence of oxygenic photosynthesis on the basis of microfossil morphologies similar to those of oxygenic cyanobacteria, stromatolite-like constructions resembling those produced by oxygenic photosynthetic microbial mats, and carbon isotope compositions consistent with fractionation by oxygenic photosynthesisers. These interpretations are contested, however: the microfossils are probably hydrothermal precipitations (Brasier et al. 2002), the stromatolite-like structures are most likely to have been produced by anoxygenic photosynthesisers (Allwood et al. 2006), and the isotopic fractionation range of oxygenic photosynthesisers overlaps with that of other microorganism groups, such as anoxygenic photosynthesisers (Reysenbach and Cady 2001). Nevertheless, another argument for oxygenic conditions based on possible evidence for transported uranium (uranium can only be transported in the oxidized state) in rocks $>3.7$ Ga-old was put forward by Rosing and Frei (2004). Data from younger 
2.5 to 2.9 Gyr old sediments based on (a) redox-sensitive metals (Anbar et al. 2007), (b) sedimentology and micropaleontology (Buick 1992; Kazmierczak and Altermann 2002) and (c) carbon isotopic measurements (Nisbet et al. 2007; Thomazo et al. 2011) also suggest the existence of oxygen and oxygenic photosynthesis, therefore strongly supporting model (ii). Finally, a recent modeling study, based on protein folding, proposes a molecular clock according to which oxygenic photosynthesis appeared 2.9 Gyr ago (Wang et al. 2011). The appearance of this metabolic process is a key step in the evolution of life towards large and complex organisms (Catling et al. 2005).

This study aims at investigating a new potential marker of oxygenic photosynthesis, by using a comparative approach between modern microbial mats and natural chert samples. Photosynthetic microbial mats are considered to be modern analogues of ancient stromatolites (Schopf et al. 1983). Samples were collected in the lake "La Salada de Chiprana" (Spain), the only permanent hypersaline ecosystem in Western Europe (Vidondo et al. 1993). Grown in a shallow-water environment, the complex microbial mats present in "La Salada de Chiprana" contain two types of bacteria using oxygenic and anoxygenic photosynthesis (Jonkers et al. 2003), respectively Microcoleus-like bacteria (MLB) (cyanobacteria) and Chloroflexus-like bacteria (CLB) (chloroflexacea). Comparison of mat samples enriched in each of these two bacteria was performed using Electron Paramagnetic Resonance (EPR) spectroscopy. This spectroscopy detects the electron spin of organic radicals in carbonaceous matter with high sensitivity (Uebersfeld and Erb 1956) and has therefore already been used to characterize the maturation of polyaromatic organic matter in coals (Retcofsky et al. 1968; Villey et al. 1981; Oberlin et al. 1978; Mrozowski 1988a, b; Rouzaud et al. 1991) in Precambrian cherts (Skrzypczak-Bonduelle et al. 2008) and in meteorites (Binet et al. 2002, 2004; Gourier et al. 2008). The radicals detected by EPR consist of more or less complex aromatic moieties (with $\mathrm{sp}^{2}$ carbons), where the unpaired electron spin occupies a $\pi$-type molecular orbital. Several parameters can be deduced from the EPR line based on the amplitude, the width and the resonance field of the signal. Those parameters were determined during analysis of thermally treated biomass mainly comprising oxygenic and anoxygenic photosynthetic bacteria and were compared with various Precambrian chert samples.

\section{Material and Methods}

\section{Material}

"La Salada de Chiprana", located in the Ebro River basin, northern Spain $\left(41^{\circ} 14^{\prime} 30^{\prime \prime} \mathrm{N}, 0^{\circ} 10^{\prime} 50^{\prime \prime} \mathrm{W}\right)$, is a hypersaline lake (78\%) in which the most abundant ions are $\mathrm{Mg}^{2+}$ and $\mathrm{SO}_{3}{ }^{2-}$ (Vidondo et al. 1993; Jonkers et al. 2003). With a total surface of 31 ha and a maximum depth of $5.6 \mathrm{~m}$, the lake lies on the Upper Oligocene-Miocene Caspe Formation, which is mainly composed of sand and silt stones. The lake hosts extensive microbial mats, exhibiting a multilayer structure and containing MLB and CLB.

MLB is a mat-building cyanobacterium, common in marine and hypersaline environments. In laboratory experimental conditions, it has been shown capable of oxygenic photosynthetic activity at

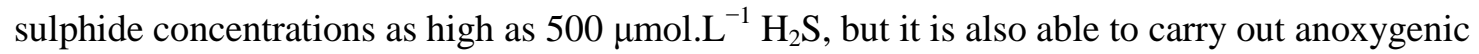
photosynthesis using sulphide as an electron donor (Jørgensen et al. 1986). During the day, MLB has a high rate of $\mathrm{CO}_{2}$ fixation (Guerrero and De Wit 1992). In situ measurements of oxygen dynamics during daily cycles have shown that oxygen concentration increases directly after sunrise and rapidly reaches over five times air saturation (Jonkers et al. 2003; Ludwig et al. 2005).

CLB are multicellular anoxygenic, filamentous, green non-sulphur bacteria that can use anoxygenic photosynthesis to produce chemical energy in the form of the adenosine triphosphate (ATP) molecule (Pierson and Castenholz 1995). They are characterized by the production of bacteriochlorophyll a 
(BChla), and in some species, by the additional production of BChlc or BChld. Chloroflexus aurantiacus, one of the most studied species of the phylum, is a thermophilic species (Pierson and Castenholz 1974). However, the presence of a diverse number of Chloroflexus-like organisms is also reported in intertidal marine and submerged hypersaline microbial mats (Pierson et al. 1994). In the "La Salada de Chiprana" lake, 16 phylotypes of the phylum Chloroflexus, were identified (Bachar et al. 2007). These anoxygenic, facultative anaerobic organisms may have played an important role in the evolution of photosynthesis, given their characteristics close to both green sulphur bacteria and purple bacteria, as well as their ability to perform cellular respiration in aerobic environments (Bruce et al. 1982).

$20 \mathrm{~cm} * 10 \mathrm{~cm} * 10 \mathrm{~cm}$ portions of the microbial mats were sampled in July and October 2010 and cultured in laboratory, in aerated natural lake water, at ambient temperature, and under Philips-HPI T Plus $400 \mathrm{~W}$ lamps. Routine microsensor profiling of oxygen concentrations carried out in microbial mats of the same sampling sites showed no significant change in oxygen metabolism during the maintenance period in these conditions (Ludwig et al. 2006). The microbial mats were dissected using magnifying glasses in order to separate layers dominated by MLB from those dominated by CLB. The microbial composition in the two subsamples was checked using optical microscopy (Fig. 1). Jonkers et al. (2003) reported the presence of smaller organisms, such as diatoms, in the mat that occur in both samples. The bacteria were rinsed twice with distilled water, frozen and then lyophilized. Note that no significant change occurred in the microbial composition of the mat between July and October 2010 and that the same dissection protocol was used.
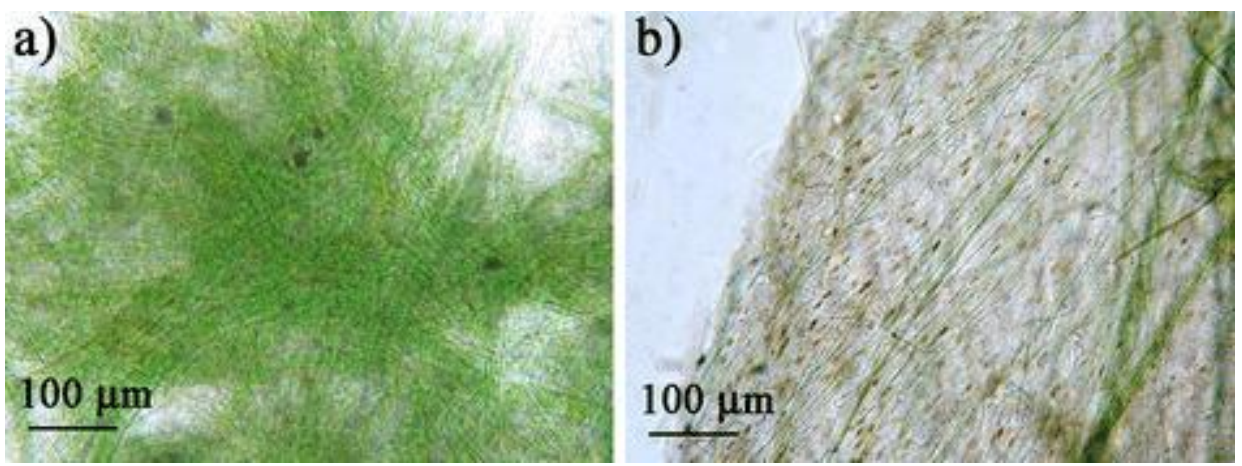

Fig. 1

Optical microscopy of an aliquot of (a) the first bacteria sample, revealing MLB colonies (b) the second bacteria sample, revealing the presence of CLB (small filaments), together with Diatoms (small ovals) and few MLB (large filaments)

Nine natural cherts of various ages, metamorphic facies, and geographical origins were also studied for comparison. Data resulting from a previous study of 12 other natural chert samples were included in this study (Skrzypczak-Bonduelle et al. 2008). The sample characteristics are given in Table 1. All selected cherts had a metamorphic grade lower than the greenschist facies. These cherts are silicified sediments containing the carbonaceous remains of microorganisms (and macroorganisms in the most recent samples). The silica phase in the cherts is microcrystalline quartz. 
Table 1

Description of the studied chert samples

\begin{tabular}{|c|c|c|c|c|c|}
\hline $\mathbf{N}^{\circ}$ & Reference & $\begin{array}{l}\text { Age } \\
\text { (Gyr) }\end{array}$ & Location & $\begin{array}{l}\text { Metamorphic } \\
\text { facies }\end{array}$ & Reference \\
\hline 1 & $\begin{array}{l}\text { Zalesie Nowe } \\
\text { a }\end{array}$ & 0.42 & $\begin{array}{l}\text { Zalesie Nowe, Holy Cross Mountains, } \\
\text { Bardo Syncline, Poland }\end{array}$ & p.p. to p.a. & $\begin{array}{l}\text { Kremer and } \\
\text { Kazmierczak } \\
2005\end{array}$ \\
\hline 2 & Zdanow $^{a}$ & 0.42 & $\begin{array}{l}\text { Zdanow, Bardzkie Mountains, Sudetes } \\
\text { Mountains, Poland }\end{array}$ & p.p. to p.a. & Kremer 2006 \\
\hline 3 & Doushantuo $^{\mathrm{b}}$ & 0.58 & $\begin{array}{l}\text { Doushantuo Formation, Yangtze } \\
\text { Block, China (1a of 8/25/83) }\end{array}$ & lower gs. & / \\
\hline 4 & Gunflint $^{\mathrm{b}}$ & 1.9 & $\begin{array}{l}\text { Gunflint Iron Formation, Port Arthur } \\
\text { Homocline, Canada ( } 3 \text { of } 06 / 30 / 84 \text { ) }\end{array}$ & lower gs. & $\begin{array}{l}\text { Awramik and } \\
\text { Barghoorn } 1977\end{array}$ \\
\hline 5 & Fortescue $^{\mathrm{b}}$ & 2.7 & $\begin{array}{l}\text { Jeerinah Formation, Fortescue Group, } \\
\text { Hamersley, Australia (3 of 10/25/92) }\end{array}$ & p.p. to p.a. & / \\
\hline 6 & Buck Reef $^{c}$ & 3.42 & $\begin{array}{l}\text { Buck Reef, Kromberg Formation, } \\
\text { Onverwacht Group, Barberton } \\
\text { Greenstone Belt, South Africa } \\
\text { (99SA03) }\end{array}$ & gs. to amp. & / \\
\hline 7 & $\begin{array}{l}\text { Middle } \\
\text { Marker }^{c}\end{array}$ & 3.72 & $\begin{array}{l}\text { Middle Marker, Komati Formation } \\
\text { Barberton Greenstone Belt, South } \\
\text { Africa (07SA22) }\end{array}$ & gs. to amp. & / \\
\hline 8 & Dresser $^{\mathrm{d}}$ & 3.5 & $\begin{array}{l}\text { Dresser Formation (ex Towers } \\
\text { Formation), Warrawoona Group, } \\
\text { Pilbara Block, Australia (PPRG006) }\end{array}$ & p.p. to lower gs. & $\begin{array}{l}\text { Schopf et al. } \\
1983\end{array}$ \\
\hline A & Rhynie $^{\text {b }}$ & 0.40 & $\begin{array}{l}\text { Rhynie Formation, Aberdeenshire, } \\
\text { Scotland }\end{array}$ & n.m. & / \\
\hline B & 2.1 of $7 / 3 / 86$ & 0.65 & $\begin{array}{l}\text { Dengying Formation, Wangfengang } \\
\text { section, China }\end{array}$ & n.m. & / \\
\hline $\mathrm{C}$ & 2 of $8 / 18 / 83^{b}$ & 1.5 & Dahongyu Formation, Hebei, China & n.m. & 1 \\
\hline $\mathrm{D}$ & 1 of $8 / 23 / 86^{b}$ & 1.9 & $\begin{array}{l}\text { Gunflint Formation, Schreiber Beach } \\
\text { Locality, Ontario, Canada }\end{array}$ & lower gs. & / \\
\hline
\end{tabular}




\begin{tabular}{|c|c|c|c|c|c|}
\hline $\mathbf{N}^{\circ}$ & Reference & $\begin{array}{l}\text { Age } \\
(\text { Gyr })\end{array}$ & Location & $\begin{array}{l}\text { Metamorphic } \\
\text { facies }\end{array}$ & Reference \\
\hline $\mathrm{E}$ & PPRG059 ${ }^{d}$ & 2.0 & $\begin{array}{l}\text { Duck Creek Dolomite, Wyloo Group, } \\
\text { Ashburton trough, Australia }\end{array}$ & p.p. to p.a. & $\begin{array}{l}\text { Schopf et al. } \\
1983\end{array}$ \\
\hline $\mathrm{F}$ & PPRG204 ${ }^{\mathrm{d}}$ & 2.3 & $\begin{array}{l}\text { Transvaal supergroup, Transvaal } \\
\text { Basin, South Africa }\end{array}$ & n.m. & $\begin{array}{l}\text { Schopf et al. } \\
1983\end{array}$ \\
\hline G & $\begin{array}{l}6 \text { of } 10 / 25 / 92 \\
b\end{array}$ & 2.7 & $\begin{array}{l}\text { Jeerinah Formation, Fortescue Group, } \\
\text { Hamersley Basin, Australia }\end{array}$ & p.p. to p.a. & / \\
\hline $\mathrm{H}$ & $\begin{array}{l}2 \text { of } 16 / 09 / 65 \\
b\end{array}$ & 3.4 & $\begin{array}{l}\text { Onverwacht Group, Barberton } \\
\text { Greenstone Belt, South Africa }\end{array}$ & gs. to amp. & / \\
\hline I & $\begin{array}{l}4.1 \text { of } \\
15 / 09 / 65^{b}\end{array}$ & 3.4 & $\begin{array}{l}\text { Onverwacht Group, Barberton } \\
\text { Greenstone Belt, South Africa }\end{array}$ & gs. to amp. & / \\
\hline $\mathrm{J}$ & $\begin{array}{l}\text { Zwartkoppie } \\
\text { d }\end{array}$ & 3.4 & $\begin{array}{l}\text { Zwartkoppie Formation, Onverwacht } \\
\text { Group, Barberton Greenstone Belt, } \\
\text { South Africa (PPRG198) }\end{array}$ & gs. to amp. & $\begin{array}{l}\text { Schopf et al. } \\
1983\end{array}$ \\
\hline $\mathrm{K}$ & PPRG002 ${ }^{\mathrm{d}}$ & 3.5 & $\begin{array}{l}\text { Dresser Formation (ancient Towers } \\
\text { Formation), Warrawoona Group, } \\
\text { Pilbara Craton, Australia }\end{array}$ & p.p. to lower gs. & $\begin{array}{l}\text { Schopf et al. } \\
1983\end{array}$ \\
\hline $\mathrm{L}$ & PPRG006 ${ }^{\mathrm{d}}$ & 3.5 & $\begin{array}{l}\text { Dresser Formation (ancient Towers } \\
\text { Formation), Warrawoona Group, } \\
\text { Pilbara Craton, Australia }\end{array}$ & p.p. to lower gs. & $\begin{array}{l}\text { Schopf et al. } \\
1983\end{array}$ \\
\hline
\end{tabular}

New samples are designated by numbers (1 to 8), samples previously studied by SkrzypczakBonduelle et al. (2008) are designated by letters (A to L). Samples were collected by ${ }^{\mathrm{a}} \mathrm{B}$. Kremer, ${ }^{b}$ S.M. Awramik, ${ }^{c}$ F. Westall and ${ }^{d}$ J.W. Schopf. Metamorphic facies is indicated as follows: n.m. for non metamorphized, p.p. for prehnite pumpellyite, p.a. for pumpellyite actinolite, gs. for greenschist and amp. for amphibolite

\section{Methods}

Kerogen isolation was performed using an $\mathrm{HF} / \mathrm{HCl}$ acidic treatment (Durand and Nicaise 1980).

Optical microscopy of modern bacteria was performed using a Leica DLMB microscope in transmitted mode, equipped with a 205 Leica C Plan 506076 objective. 3 to $4 \mathrm{mg}$ of lyophilized CLB and 5 to $10 \mathrm{mg}$ of lyophilized MLB were placed in EPR tubes in quadruplicates. A 1:1 mixture of MLB and CLB was obtained by crushing $10.3 \mathrm{mg}$ of lyophilized CLB and $10.3 \mathrm{mg}$ of lyophilized MLB in a glass mortar. 4 to $6 \mathrm{mg}$ of the mixture was then introduced into EPR tubes in duplicates. About $100 \mathrm{mg}$ of intact chert rock were sampled and analyzed by EPR without further preparation.

All EPR tubes were sealed under vacuum in order to eliminate $\mathrm{O}_{2}$. The accelerated ageing consisted in thermal treatment in gradual steps from $20{ }^{\circ} \mathrm{C}$ to $720^{\circ} \mathrm{C}$. Each step consists in a $50{ }^{\circ} \mathrm{C}$ rise of temperature for 15mn (Skrzypczak-Bonduelle et al. 2008). 
EPR analyses were performed at ambient temperature and at X-band $(9.5 \mathrm{GHz})$ on a Bruker ELEXSYS E500 spectrometer equipped with a high sensitivity Bruker 4122SHQE/0111 microwave cavity. A $2 \mathrm{~mW}$ to $20 \mathrm{~mW}$ microwave power was used. The spectrometer was calibrated using the diphenylpicrylhydrazyl (DPPH) standard with a known $\mathrm{g}$ factor $(\mathrm{g}=2,0037)$.

High-resolution transmission electron microscopy (HRTEM) is a relevant tool for obtaining information on the organization of carbonaceous matter (structure, nanostructure, texture) by imaging directly the profile of the polyaromatic layers (Oberlin 1989). Observations were carried out using a Jeol 2011 microscope operating at $200 \mathrm{keV}$. Image analysis was conducted after skeletonization as described by Rouzaud and Clinard (2002).

Raman spectra were obtained using a Renishaw InVIA Reflex microspectrometer equipped with a 514-nm Spectra Physics argon laser at $20 \mathrm{~mW}$. The laser was focused on the sample using a DMLM Leica microscope with a $100 \mathrm{X}$ objective. The laser power at the sample surface was set at around $1 \mathrm{~mW}$. The signal was detected by a Peltier cooled RENCAM CCD detector. The spectrometer was calibrated using a silicon standard before each session. Kerogens isolated from cherts and carbonaceous matter from $720{ }^{\circ} \mathrm{C}$ thermally treated MLB and CLB were crushed in an agate mortar before deposition on a glass slide for analysis.

\section{Results and Discussion}

\section{Optical Microscopy of Bacterial Samples}

Observation of the separated bacteria using optical microscopy revealed that the first batch, which was sampled in the upper layer of the microbial mat, is chiefly composed of MLB colonies (Fig. 1a), whereas the second batch, sampled right under the first layer, is mainly composed of CLB, together with diatoms and few MLB filaments (Fig. 1b).

It is obvious that perfect separation of the two bacteria is not possible. However, the optical images show that each dissected layer was dominated by one of the bacteria species. The other organisms reported by Jonkers et al. (2003) contribute to each dissected layer and are therefore taken as part of the background signal.

\section{EPR Study of the Thermally Treated Bacteria}

Three main parameters (described on Fig. 2a) can be derived from EPR lines of radicals in the disordered carbonaceous matter within each sample. The peak-to-peak amplitude $A_{p p}$, for a given peak-to-peak linewidth $\Delta \mathrm{B}_{\mathrm{pp}}$, reflects the number of spins in the sample, which is directly related to the total amount of radicals. When $\Delta \mathrm{B}_{\mathrm{pp}}$ varies, the line intensity is calculated as $\mathrm{I}=\mathrm{A}_{\mathrm{pp}} \cdot \Delta \mathrm{B}_{\mathrm{pp}}{ }^{2}$. To avoid consideration of the mass of organic matter introduced in the tube, each thermal treatment series on a sample was normalized so that the maximum intensity attained was equal to 1 . The g-factor, calculated from the resonance field of the signal, reflects the chemical composition of the radicals. Its deviation from the free spin value $\left(\mathrm{g}_{\mathrm{e}}=2.0023\right)$ increases with the $\mathrm{O} / \mathrm{C}$ ratio (Retcofsky et al. 1968; Rouzaud et al. 1991). The peak-to-peak linewidth $\Delta \mathrm{B}_{\mathrm{pp}}$ reflects the diversity of organic radicals (distribution of radicals), their local concentration (dipolar interaction), and the hydrogen content (unresolved hyperfine interaction) (Skrzypczak-Bonduelle et al. 2008). 
a)

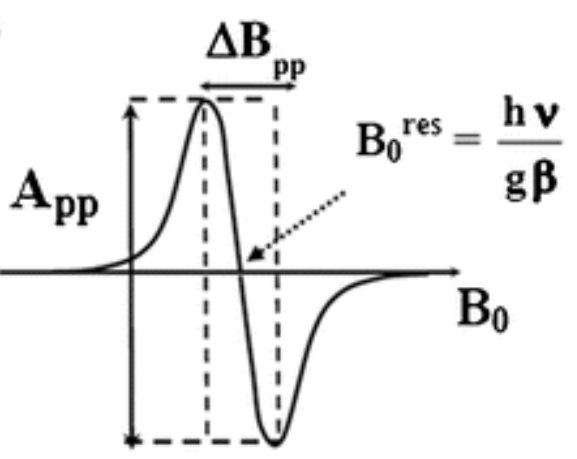

b) $M L B$
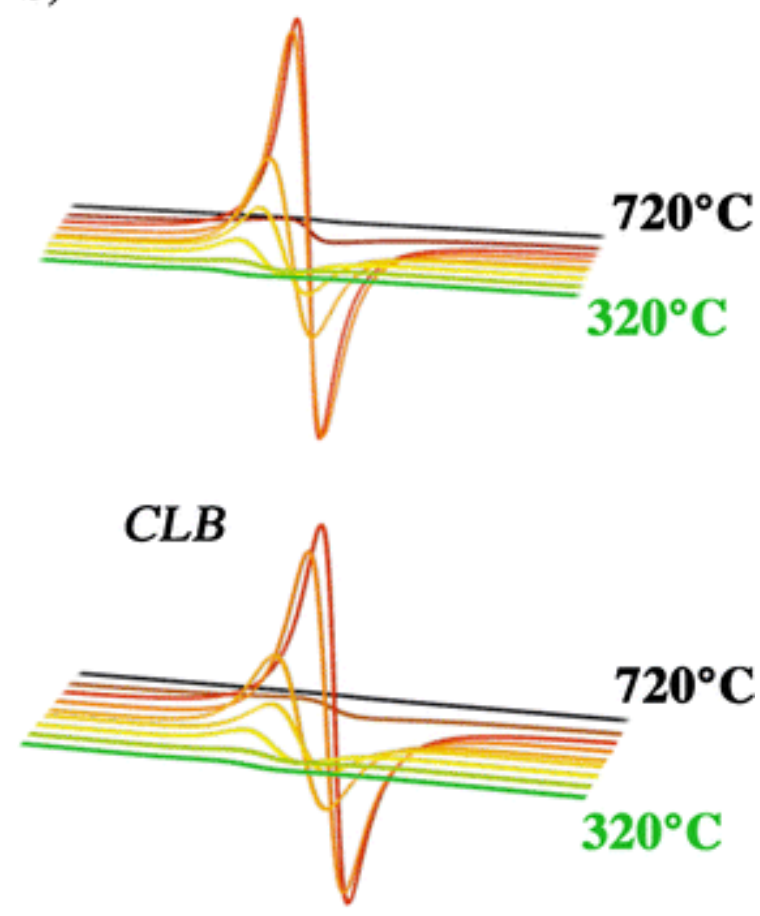

Fig. 2

a Definition of parameters measured on the EPR line of radicals in carbonaceous matter (b) EPR spectra of the thermally treated bacteria

The evolution of the EPR spectra and their associated parameters during thermal treatment of the two types of bacteria is shown in Figs. $2 \mathrm{~b}$ and 3 respectively. Only the $320^{\circ} \mathrm{C}$ to $720{ }^{\circ} \mathrm{C}$ temperature range is represented for the thermal treatment since there is no significant EPR signal for samples treated at lower temperatures. Moreover, the EPR line shape evolution during thermal treatments is the same for both samples, from Gaussian to Lorentzian and then to a stretched-Lorentzian shape, and is therefore not reported here. Three domains (II, III and IV) of evolution of the organic matter in chert samples in the $320{ }^{\circ} \mathrm{C}$ to $720{ }^{\circ} \mathrm{C}$ temperature range were previously distinguished (Skrzypczak-Bonduelle et al. 2008). Note that Domain I is not mentioned in this paper, since it describes organic matter that underwent thermal treatment lower than $320^{\circ} \mathrm{C}$, for which, as mentioned above, no significant EPR signal was observed. Both types of bacteria show the same EPR behavior with increasing temperature, as described below. 
a)



b)

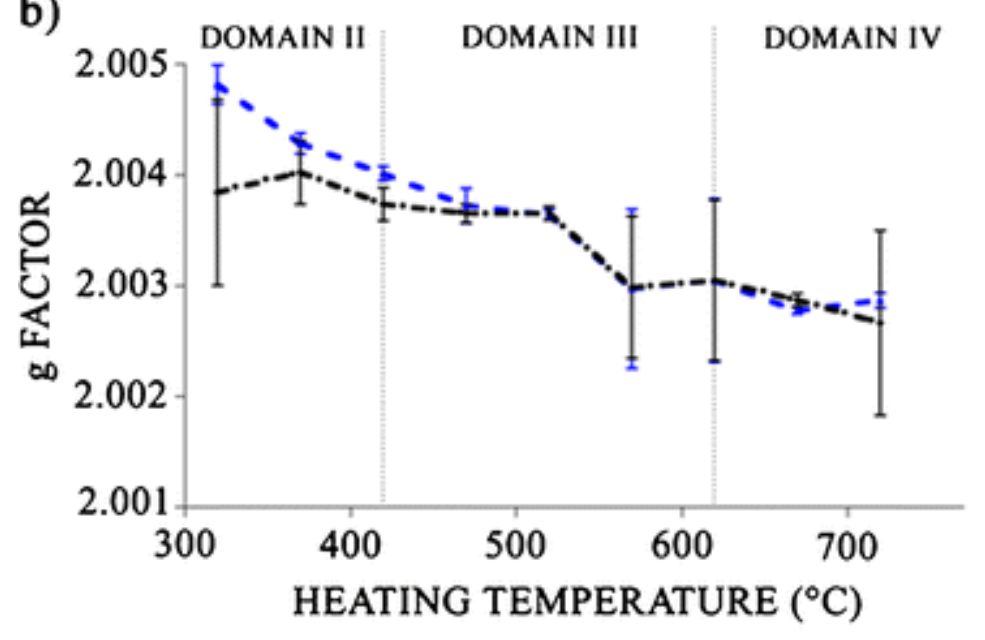

c)

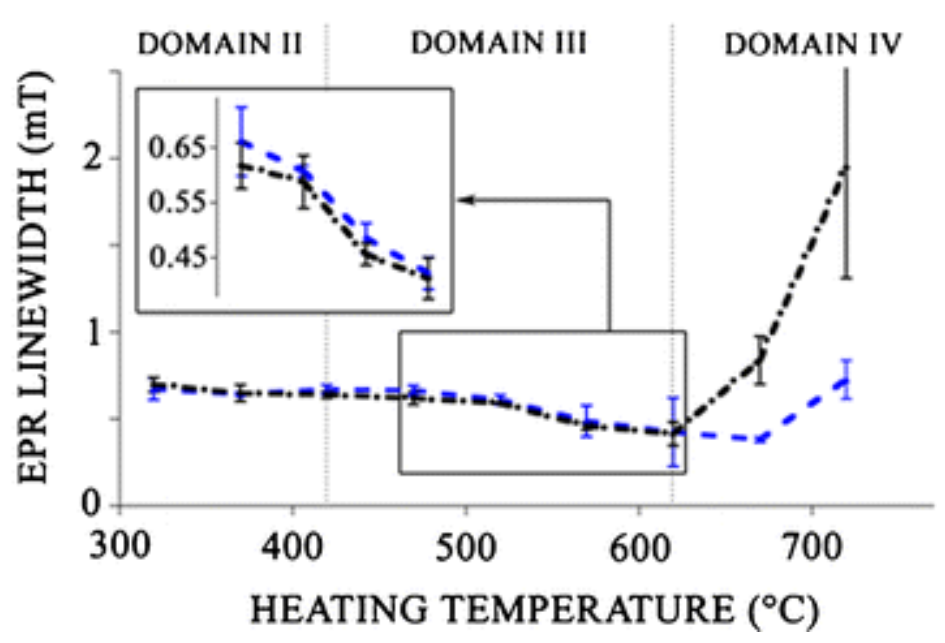

Fig. 3

Evolution of (a) the normalized intensity (b) the g-factor and (c) the peak-to-peak linewidth of the EPR signal of thermally treated MLB (mixed black line) and CLB (dashed blue line). Error bars reflect the dispersion of the values for the quadruplicate 
Domain II ranges from about $320^{\circ} \mathrm{C}$ to about $450{ }^{\circ} \mathrm{C}$, the temperature range in which there is a loss of carboxyl and hydroxyl groups. In this particular study, EPR spectra in Domain II show a slight increase in their intensity, an almost steady g-factor, and an almost constant linewidth indicating that no C-H hydrogen loss occurs in this temperature range.

Domain III is defined for thermal treatment from about $450{ }^{\circ} \mathrm{C}$ to about $620{ }^{\circ} \mathrm{C}$, a temperature range in which hydrocarbon loss occurs. In this study, there is a drastic increase in the intensity, and a slight decrease in the EPR linewidth in Domain III (see insert in Fig. 3c), revealing an increase in radical concentration. A slight decrease in the g-factor is observable (Fig. 3b), pointing to the loss of some heteroelements, mainly oxygen. The linewidth decrease in this domain reveals a hydrogen loss (Skrzypczak-Bonduelle et al. 2008).

Domain IV, for thermal treatment higher than about $620^{\circ} \mathrm{C}$, is characterized by a sharp decrease in intensity, indicating that the recombination rate of radicals is faster than their creation rate, the concentration of which reached a maximum (Fritsch et al. 1974). The g-factor remains constant, pointing to no significant change in the chemical nature of the radicals. Surprisingly, there is significant broadening in linewidth, especially for the MLB sample. The linewidth at $720{ }^{\circ} \mathrm{C}$ for MLB and CLB is $1.9 \pm 0.6 \mathrm{mT}$ and $0.7 \pm 0.1 \mathrm{mT}$ respectively. Four hypotheses can be put forward to account for this selective broadening:

(i)

Unresolved hyperfine interaction between the radicals and the hydrogen nuclei (Retcofsky et al. 1975). However, as highlighted in the insert in Fig. 3c, the linewidth decreases at the beginning of Domain III. This is related to hydrogen loss and thus rules out any major hyperfine interaction between the radicals and hydrogen nuclei.

The presence of molecular dioxygen $\mathrm{O}_{2}$, which is paramagnetic, and interacts with organic radicals, resulting in an EPR line broadening by dipolar interactions (Bates et al. 1995). This hypothesis appears unlikely owing to the fact that all EPR experiments were conducted under vacuum.

The creation of a new type of radical due to specific organic precursors in the organic matter of MLB. This hypothesis appears unlikely, given that organic functions are removed from the carbonaceous matter during the first stages of carbonization. On the contrary, the EPR linewidth difference occurs only for the higher stages of carbonization, in which radicals recombine and are annihilated.

Selective modification of radicals due to high temperature reactions. This reaction may be catalyzed by an element (e.g. a transition metal, ...) associated with the organic matter of MLB only. This hypothesis appears the most likely and is developed below. 
In the absence of hydrogen, which is the case during the highest stage of carbonization (domain IV), the EPR linewidth is driven by the distance $\mathrm{R}$ between unpaired electron spins, i.e. between radicals: the larger the distance, the smaller the linewidth, which varies as $\mathrm{R}^{-3}$ due to dipolar interactions between electron spins. Statistical theory predicts that the linewidth of a Lorentzian line (which is the case in the present study) in a magnetically diluted spin system is related to the spin concentration $\mathrm{N}$ by (Abragam 1961):

$$
\triangle B_{p p}=4 \pi 29 g \beta N \approx 8.12 \times 10-21 N
$$

with $\mathrm{N}$ in $\mathrm{cm}^{-3}$ and $\Delta \mathrm{B}$ pp in $\mathrm{mT}$. In the following, we distinguish between the mean spin concentration $\mathrm{N}$ in the sample, which is directly measured by the EPR intensity, and the local spin concentration $\mathrm{N}$ loc experienced by each radical, which is measured by the linewidth. Figure 3 a shows that the EPR intensity and thus the mean concentration $\mathrm{N}$ decreases above $600{ }^{\circ} \mathrm{C}$. Assuming an homogeneous distribution of radicals in the $620^{\circ} \mathrm{C}$ carbonized material and using Eq. 1, we may calculate the spin concentration at $620^{\circ} \mathrm{C} \mathrm{N} \approx \mathrm{N}_{\text {loc }} \approx 0.5 \times 10^{20} \mathrm{~cm}^{-3}$. At $720^{\circ} \mathrm{C}$, the EPR intensity decreases by a factor $\approx 6$ for MLB, which means that $\mathrm{N}$ decreases by the same factor. Thus the mean spin concentration $\mathrm{N}$ in MLB at $720{ }^{\circ} \mathrm{C}$ is $\mathrm{N} \approx 0.8 \times 10^{19} \mathrm{~cm}^{-3}$. However, due to the linewidth broadening, when using Eq. 1 , we find that $\mathrm{N}_{\text {loc }} \approx 2.5 \times 10^{20}$ in MLB.

This implies that the global spin concentration $\mathrm{N}$ decreases in MLB between $620^{\circ} \mathrm{C}$ and $720{ }^{\circ} \mathrm{C}$, while the local spin concentration $\mathrm{N}_{\text {loc }}$ increases in the same temperature range. This points to the formation of shallow radical aggregates characterized by their local concentration $\mathrm{N}_{\text {loc }}>\mathrm{N}$ (Eq. 1). Such a formation of radical aggregates is consistent with formation at a local scale, possibly related to a catalytic effect. To have a better understanding of the origin of these shallow aggregates of radicals, Raman spectroscopy and HRTEM analyses of the carbonized bacteria were run.

\section{Raman Spectroscopy and HRTEM of the Thermally Treated Bacteria}

Raman spectroscopy and HRTEM were performed on the $720{ }^{\circ} \mathrm{C}$ thermally treated bacteria for which the EPR linewidth difference is the largest. The Raman spectra of the heated microorganisms are very similar, as shown in Fig. 4, with two main bands at 1,344 and $1,570 \mathrm{~cm}^{-1}$. The spectra were deconvoluted with a four-band fitting (G, D1, D2 and D3) using a Voigt profile, as described in Beyssac et al. (2002). This allowed determination of the position, intensity, area and width for each band. Raman parameters were calculated (Table 2), comprising the D1 full-width at half maximum $\left(\mathrm{cm}^{-1}\right)$, along with the $\mathrm{R} 1$ and $\mathrm{R} 2$ ratios, defined as: $R 1=\operatorname{Intensity}(D 1) \operatorname{Intensity}(G)$ and $R 2=\operatorname{Area}(D 1) \operatorname{Area}(G+D 1+D 2+D 3)$ (Beyssac et al. 2003). The D1 full-width at half maximum is known to decrease, with increasing degree of organization in the carbonaceous matter, whereas the R1 and R2 ratios increase (Beyssac et al. 2003; Bernard et al. 2010). In the case of the $720{ }^{\circ} \mathrm{C}$ thermally treated bacteria, Raman parameters are similar (Table 2), thus indicating that the organic matter in the thermally treated MLB and CLB has the same structure. 
a)
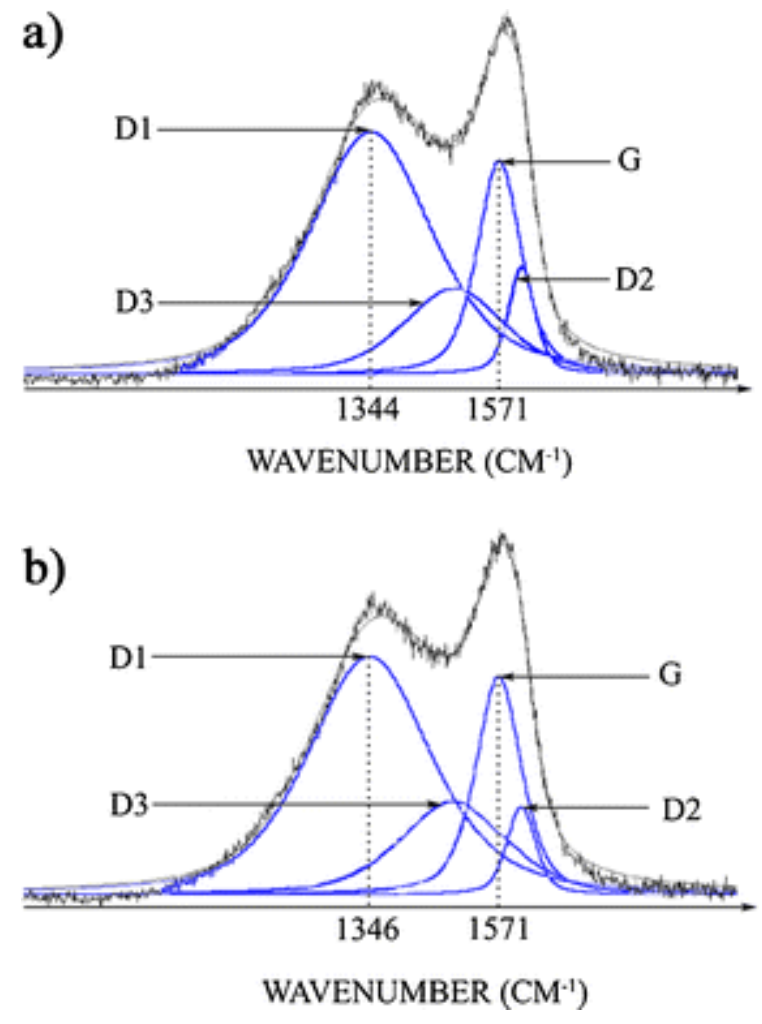

Fig. 4

Raman spectra of $720{ }^{\circ} \mathrm{C}$ thermally treated (a) CLB and (b) MLB bacteria

\section{Table 2}

Raman parameters for $720{ }^{\circ} \mathrm{C}$ thermally treated Chloroflexus-like bacteria (CLB) and Microcoleus-like bacteria (MLB)

\begin{tabular}{|l|l|l|l|}
\hline & D1 full-width at half maximum $\left(\mathrm{cm}^{-\mathbf{1}}\right)$ & R1 ratio & R2 ratio \\
\hline MLB & $262 \pm 12$ & $1.13 \pm 0.06$ & $0.61 \pm 0.02$ \\
\hline CLB & $264 \pm 5$ & $1.09 \pm 0.06$ & $0.59 \pm 0.02$ \\
\hline
\end{tabular}

Error bars reflect measurement errors

HRTEM observations were run on the $720^{\circ} \mathrm{C}$ thermally treated MLB and CLB (Fig. 5). Associated HRTEM parameters (Table 3) were calculated from skeletonization of the HRTEM images of the two samples (as illustrated in Fig. 5a, b), following the method of Rouzaud and Clinard (2002). These parameters are again very similar, confirming the similarity of the organic matter structure inferred from Raman observations. It can therefore be concluded that the degrees of carbonization of MLB and CLB are similar. 

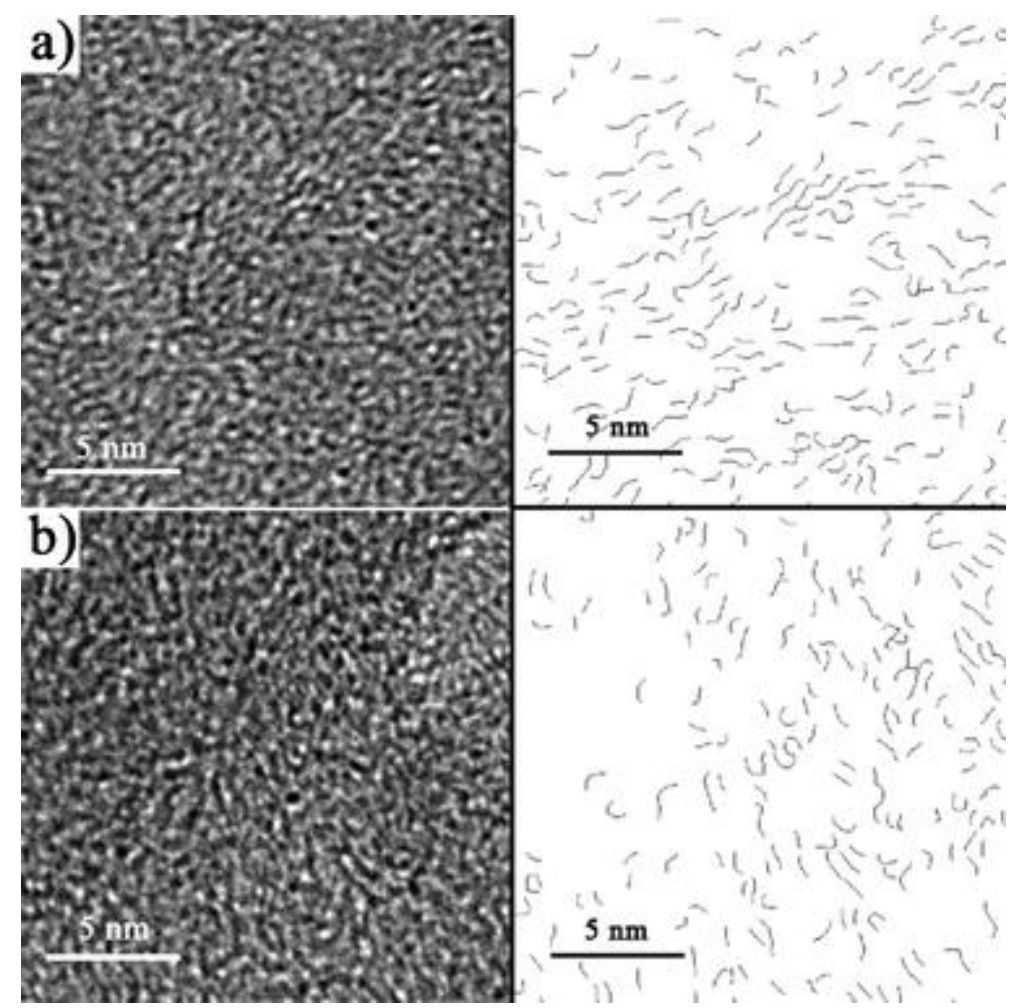

Fig. 5

High Resolution TEM images and image skeletonization of $720{ }^{\circ} \mathrm{C}$ thermally treated (a) CLB and (b) MLB bacteria

Table 3

HRTEM parameters for $720^{\circ} \mathrm{C}$ thermally treated Chloroflexus-like bacteria (CLB) and Microcoleus-like bacteria (MLB)

\begin{tabular}{|l|l|l|l|l|l|}
\hline & \% stacked layers (\%) & La (nm) & Lc (nm) & D $_{\text {moy }}(\mathbf{n m})$ \\
\hline MLB & $36 \pm 9$ & $2.2 \pm 0.2$ & $5.6 \pm 0.4$ & $4.6 \pm 0.1$ \\
\hline CLB & $40 \pm 9$ & $2.5 \pm 0.7$ & $5.7 \pm 0.3$ & $4.7 \pm 0.0$ \\
\hline
\end{tabular}

Error bars reflect measurement errors

It is important to note that radicals detected by EPR constitute only a very small part (much less than $0.1 \%$ ) of the carbonaceous matter. On the contrary, Raman spectroscopy and HRTEM reflect the totality of the material and not the close environment of the radicals influenced by the specific element contained in MLB.

In conclusion, the structure of the organic matter does not drive the EPR linewidth of the thermally treated bacteria. This confirms that the specific broadening of the EPR line is only due to the aggregation of a small quantity of radicals, which are undetectable by Raman and HRTEM. This aggregation, which occurs only in MLB, must be due to the presence of some catalytic element present in MLB and not in CLB, and which is incorporated or adsorbed on carbonaceous particles. It must be stressed that the slight linewidth increase for the CLB sample (Fig. 3c) is inferred to be due to the 
presence of small amounts of MLB in the CLB sample, due to limitations in the separation method (Fig. 1b).

\section{EPR Study of Natural Cherts}

The variation of the EPR linewidth $\left(\Delta \mathrm{B}_{\mathrm{pp}}\right)$ of 15 chert samples with ages ranging from 0.4 to $3.5 \mathrm{Gyr}$ is reported in Fig. 6. A decrease of $\Delta \mathrm{B}_{\mathrm{pp}}$ is observed from samples through the Phanerozoic and the Proterozoic. A similar trend was previously reported for coals (Retcofsky et al. 1975) and cherts (Skrzypczak-Bonduelle et al. 2008). As indicated above, this EPR line narrowing is due to progressive hydrogen loss upon ageing. For Archean samples, the $\Delta \mathrm{B}_{\mathrm{pp}}$ encompasses a large range of values, from $0.05 \mathrm{mT}$ to $0.35 \mathrm{mT}$. A similar dispersion was already reported for a smaller set of Archean cherts (Skrzypczak-Bonduelle et al. 2008). This is unlikely to result from the maturity of the sample, which is the result of age, temperature and pressure. This maturity was evaluated using the literature (Table 1) and Raman spectra of the cherts (Fig. 7, Table 4). For instance, the Buck Reef (6) and Middle Marker (7) Archean cherts have more or less the same age (3.42 and $3.72 \mathrm{Ga}$, respectively) and similar Raman spectra (Fig. 7), revealing similar metamorphic grades. However, those two samples show different linewidths (Fig. 6). Similarly, the nature of the sediment and its environment of formation do not seem to be the main cause of linewidth dispersion in Archean samples. For instance, the Middle Marker chert (7) (Lanier and Lowe 1982) and the Zwartkoppie chert (J) (Lowe and Knauth 1977) both formed in a shallow-water environment of deposition but nevertheless show different linewidths.

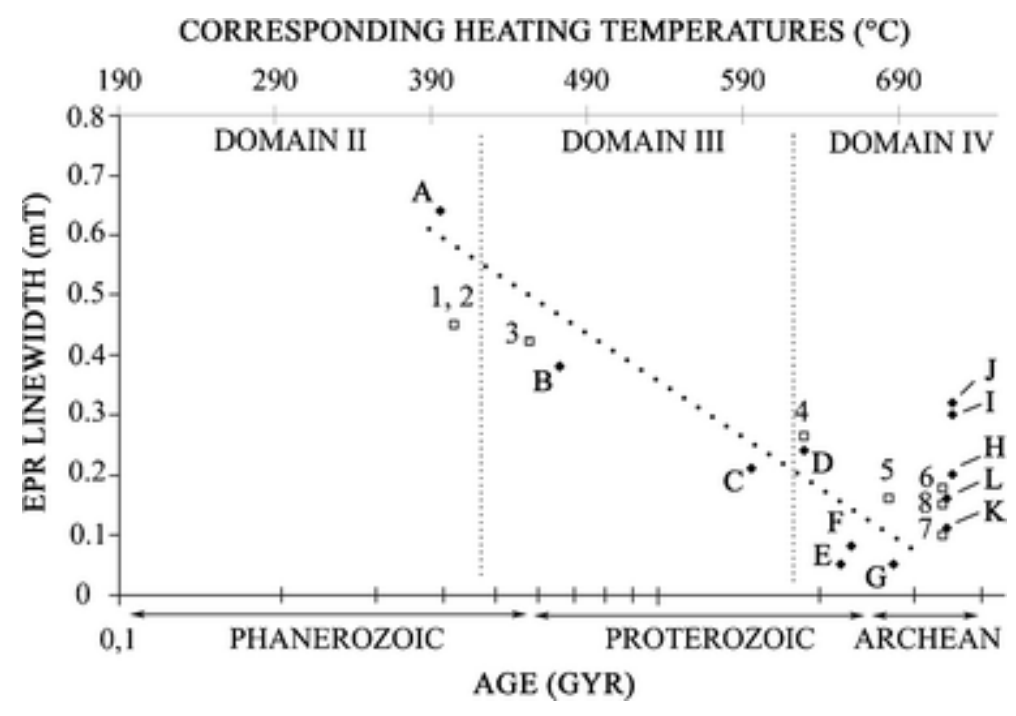

Fig. 6

Peak-to-peak width of the EPR line versus age of the studied cherts. Results from this work (numbers 1 to 8 , empty squares) and from Skrzypczak-Bonduelle et al. (2008) (letters A to L, plain diamonds). Numbers and letters refer to samples as identified in Table 1. Dotted line is a guide for the eye and does not represent any correlation 

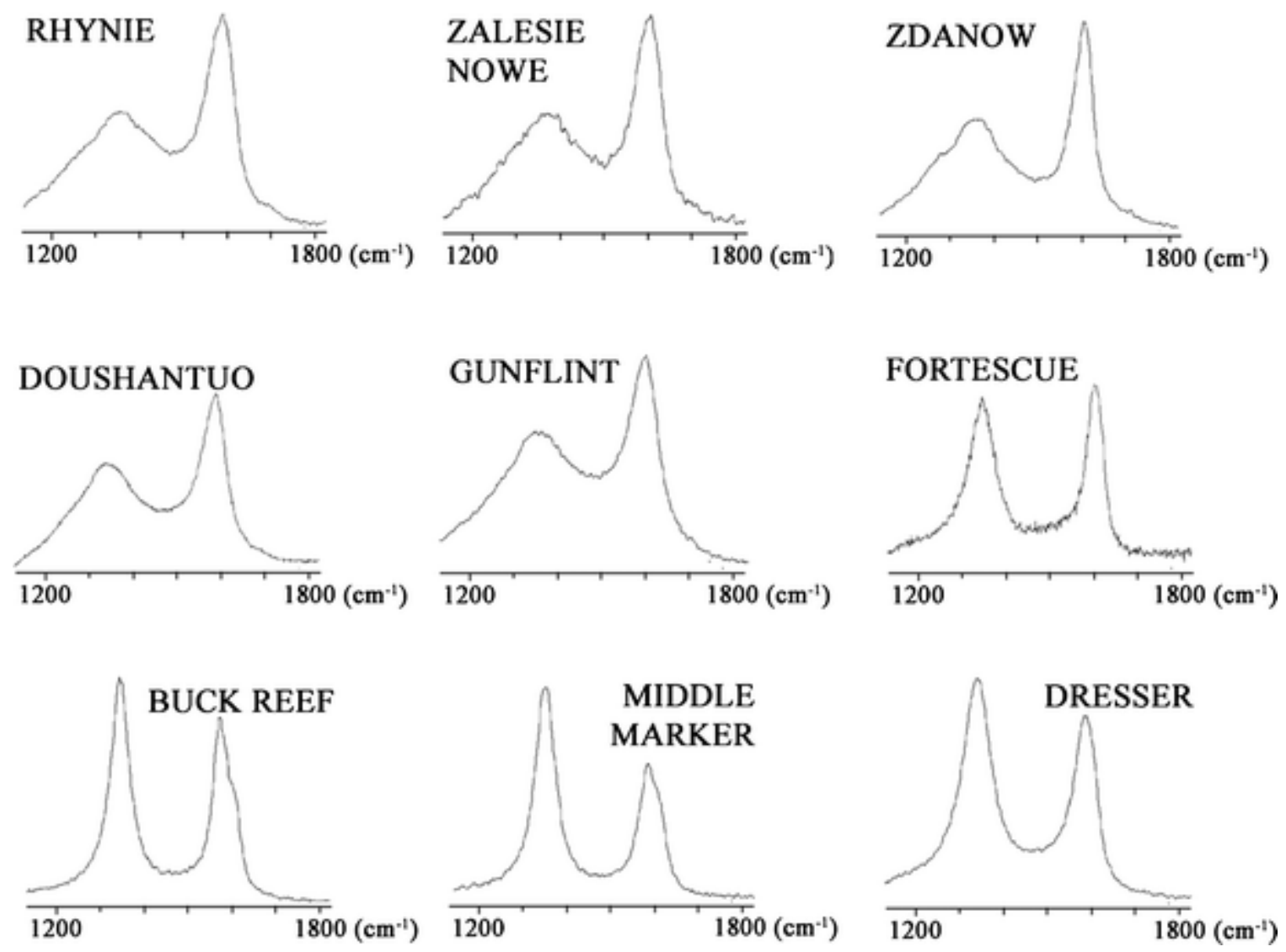

Fig. 7

Raman spectra of the carbonaceous matter in the studied cherts identified in Table 1. Only the Rhynie sample from Skrzypczak-Bonduelle et al. (2008) was available for analysis

Table 4

Raman parameters for carbonaceous matter embedded in cherts

\begin{tabular}{|l|l|l|l|l|l|c|}
\hline $\mathbf{N}^{\circ}$ & Chert reference & Age (Gyr) & FWMH (G) & FWMH (D1) & R1 & R2 \\
\hline A & Rhynie & 0.40 & $85 \pm 6$ & $232 \pm 10$ & $0.67 \pm 0.11$ & $0.50 \pm 0.03$ \\
\hline 1 & Zalesie & 0.42 & $79 \pm 2$ & $207 \pm 3$ & $0.84 \pm 0.04$ & $0.50 \pm 0.02$ \\
\hline 2 & Zdanow & 0.42 & $67 \pm 4$ & $224 \pm 6$ & $0.86 \pm 0.03$ & $0.64 \pm 0.03$ \\
\hline 3 & Doushantuo & 0.58 & $65 \pm 4$ & $225 \pm 8$ & $0.67 \pm 0.12$ & $0.64 \pm 0.01$ \\
\hline 4 & Gunflint & 1.9 & $66 \pm 4$ & $178 \pm 6$ & $0.77 \pm 0.06$ & $0.62 \pm 0.02$ \\
\hline 5 & Fortescue & 2.7 & $50 \pm 8$ & $77 \pm 5$ & $1.99 \pm 0.61$ & $0.64 \pm 0.09$ \\
\hline 6 & Buck Reef & 3.3 & $51 \pm 8$ & $59 \pm 4$ & $1.51 \pm 0.57$ & $0.50 \pm 0.06$ \\
\hline 7 & Middle Marker & 3.4 & $60 \pm 2$ & $61 \pm 2$ & $1.70 \pm 0.10$ & $0.58 \pm 0.03$ \\
\hline 8 & Dresser & 3.5 & $57 \pm 3$ & $87 \pm 5$ & $1.35 \pm 0.09$ & $0.61 \pm 0.02$ \\
\hline
\end{tabular}

Only one sample from Skrzypczak-Bonduelle et al. (2008) was available for analysis. Error bars reflect measurement errors

If not chiefly related to the metamorphic grade, the age of the sample, or the geological setting, the EPR linewidth dispersion has to be related to the nature of the carbonaceous precursor. The $g$ factor evolution shows that heteroelements are lost during the first stage of 
carbonization. The influence of organic functions is thus unlikely and the EPR linewidth dispersion reflects the presence of some aggregates of radicals similar to those observed for MLB. Based on the aforementioned results on artificially aged microbial samples, one might assume that a specific metal element plays a catalytic role in the radical aggregation. This element could be, for example, a transition metal ion originating from a specific metalloenzyme of the metabolism of the precursor bacteria. Similar linewidth broadenings were reported by Mrozowski (1988b) during EPR study of thermally treated biological materials (higher plants), which are complex oxygenic photosynthesizers, the metabolism of which is based on metalloenzymatic activity. In a similar fashion, the EPR linewidth broadening in the cherts might be a marker of the metabolism of the micro-organisms, the remains of which are embedded in the chert.

It is important to note that if linewidth broadening in cherts may be a marker of metabolism, the absence of linewidth broadening does not imply the absence of this metabolism. Namely, transition metals are known to migrate in the mineral matrix during time and thermal events, as documented for vanadium (Gourier et al. 2010). However, the higher the organic matter concentration, the slower the migration of the transition metal (Gourier et al. 2010). Those observations imply that the aforementioned proposed marker is only applicable to chert samples having zones of concentrated organic matter. This preliminary study highlights the possibility of EPR as a potential tool to access information on the metabolism of past microorganisms, for example oxygenic photosynthesis.

\section{Conclusion}

The EPR study of thermally treated oxygenic and anoxygenic photosynthetic bacteria, MLB and CLB respectively, showed selective broadening of the EPR signal of the MLB bacteria, for thermal treatments at temperatures higher than $600{ }^{\circ} \mathrm{C}$. This difference was attributed to the presence of catalytic activity due to an element associated with MLB, creating radicals aggregates. However, despite Raman spectroscopy analysis and HRTEM observations, both showing the formation of similar carbonaceous materials, the exact nature of this reaction could not be determined. Similar broadening of EPR linewidth was also found in some natural carbonaceous Archean cherts, without any relationship to sample age, location or metamorphic grade, therefore suggesting that it might be a metabolic signature. Further analysis is needed in order to understand the mechanisms controlling this increasing linewidth in the EPR signal.

Acknowledgments

This work was supported by the Archaemat program of the French National Research Agency (ANR), by the Planetology program of Institut National des Sciences de l'Univers and the Centre National de la Recherche Scientifique (INSU/CNRS) and by the Exobiology Program of the Centre National d'Etudes Spatiales (CNES). The authors are very thankful to François Orange (CBM, Orléans, France), for his help during bacteria collection and separation. The authors also acknowledge Yann Le Du and Frederic Mentink-Vigier (LCMCP, Paris, France) for their advises and constructive reflections about EPR experiments. Finally, authors are very thankful to the reviewers for their constructive remarks. 


\section{References}

Abragam A (1961) Principle of nuclear magnetism. Clarendon, Oxford

Allwood AC, Walter MR, Kamber BS, Marshall CP, Burch IW (2006) Stromatolite reef from the Early Archaean era of Australia. Nature 441:714-718

Anbar AD, Duan Y, Lyons TW, Arnold GL, Kendall B, Creaser RA, Kaufman AJ, Gordon GW, Scott C, Garvin J, Roger B (2007) A whiff of oxygen before the Great Oxidation Event? Science 317:1903-1906

Awramik SM, Barghoorn ES (1977) The Gunflint Microbiota. Precambrian Res 5:121-142

Bachar A, Omoregie E, de Wit R, Jonkers HM (2007) Diversity and function of chloroflexuslike bacteria in a hypersaline microbial Mat: phylogenetic characterization and impact on aerobic respiration. Appl Environ Microbiol 73:3975-3983

Barley ME, Bekker A, Krapež B (2005) Late Archean to Early Paleoproterozoic global tectonics, environmental change and the rise of atmospheric oxygen. Earth Planet Sci Lett 238:156-171

Bates S, Yetkin Z, Jesmanowicz A, Hyde JS, Bandettini PA, Estkowski L, Haughton VM (1995) Artifacts in functional magnetic resonance imaging from gaseous oxygen. J Magn Reson Imaging 5:443-445

Bernard S, Beyssac O, Benzerara K, Findling N, Tzvetkov G, Brown GE Jr (2010) XANES, Raman and XRD study of anthracene-based cokes and saccharose-based chars submitted to high-temperature pyrolysis. Carbon 48:2506-2516

Beyssac O, Goffé B, Chopin C, Rouzaud JN (2002) Raman spectra of carbonaceous material in metasediments: a new geothermometer. J Metamorph Geol 20:859-871

Beyssac O, Goffé B, Petitet JP, Froigneux E, Moreau M, Rouzaud JN (2003) On the characterization of disordered and heterogeneous carbonaceous materials by Raman spectroscopy. Spectrochim Acta A 00:1-10

Binet L, Gourier D, Derenne S, Robert F (2002) Heterogeneous distribution of paramagnetic radicals in insoluble organic matter from the Orgueil and Murchison meteorites. Geochim Cosmochim Acta 66:4177-4186

Binet L, Gourier D, Derenne S, Robert F, Crofini I (2004) Occurence of abundant diradicaloid moieties in the insoluble organic matter from the Orgueil and Murchison meteorites: a fingerprint of its extraterrestrial origin? Geochim Cosmochim Acta 68:881-891

Bosak T, Greene SE, Newman DK (2007) A likely role for anoxygenic photosynthetic microbes in the formation of ancient stromatolites. Geobiology 5:119-126

Brasier MD, Green OR, Jephcoat AP, Kleppe AK, van Kranendonk M, Lindsay JF, Steele A, Grassineau N (2002) Questioning the evidence for Earth's oldest fossils. Nature 416:76-81 
Bruce BD, Fuller RC, Blankenship RE (1982) Primary photochemistry in the facultatively aerobic green photosynthetic bacterium Chloroflexus aurantiacus. Proc Natl Acad Sci U S A 79:6532-6536

Buick R (1992) The antiquity of oxygenic photosynthesis: evidence from stromatolites in sulfate-deficient Archean lakes. Science 255:74-77

Buick R (2008) When did oxygenic photosynthesis evolve? Philos Trans R Soc B 363:27312743

Catling DC, Claire MW (2005) How Earth's atmosphere evolved to an oxic state: a status report. Earth Planet Sci Lett 237:1-20

Catling DC, Glein CR, Zahnle KJ, McKay CP (2005) Why $\mathrm{O}_{2}$ is required by complex life on habitable planets and the concept of planetary "oxygenation time". Astrobiology 5:415-438

Croal LR, Jia Y, Kappler A, Newman DK (2009) Phototrophic Fe(II) oxidation in an atmosphere of H2: implications for Archean banded iron formations. Geobiology 7:21-24

Derenne S, Robert F, Skrzypczak-Bonduelle A, Gourier D, Binet L, Rouzaud JN (2008) Molecular evidence for life in the 3.5 billion year old Warrawoona chert. Earth Planet Sci Lett 272:476-480

Durand B, Nicaise G (1980) Procedures for kerogen isolation. In: Durand B (ed) Kerogen: insoluble organic matter from sedimentary rocks. Technip, Paris, pp 35-53

Farquhar J, Bao H, Thiemens M (2000) Atmospheric influence of Earth's earliest sulfur cycle. Science 289:756-758

Fritsch G, Lopez C, Rodriguez L (1974) Generation and recombination of free radicals in organic materials studied by electron spin resonance. J Magn Reson 16:48-55

Gaillard F, Scaillet B, Arndt NT (2011) Atmospheric oxygenation caused by a change in volcanic degassing pressure. Nature 478:229-232

Gourier D, Robert F, Delpoux O, Binet L, Vezin H, Moissette A, Derenne S (2008) Extreme deuterium enrichment of organic radicals in the Orgueil meteorite: revisiting the interstellar interpretation? Geochim Cosmochim Acta 72:1914-1923

Gourier D, Delpoux O, Bonduelle A, Binet L, Ciofini I, Vezin H (2010) EPR, ENDOR, and HYSCORE study of the structure and the stability of vanadyl-porphyrin complexes encapsulated in silica: potential paramagnetic biomarkers for the origin of life. J Phys Chem B $114: 3714-3725$

Guerrero MC, De Wit R (1992) Microbial mats in the inland saline lakes of Spain. Limnetica 8:197-204

Hofmann HJ, Grey K, Hickman AH, Thorpe RI (1999) Origin of 3.45 Ga coniform stromatolites in Warrawoona Group, Western Australia. Geol Soc Am Bull 111:1256-1262

Holland HD (1984) The Chemical Evolution of the Atmosphere and Oceans. Princeton Univ. Press, Princeton 
Holland HD (1999) When did the Earth's atmosphere become oxic? A reply. Geochem News 100:20-22

Holland HD (2002) Volcanic gases, black smokers, and the Great Oxidation Event. Geochim Cosmochim Acta 66:3811-3826

Javaux EJ, Marshall CP, Bekker A (2010) Organic-walled microfossils in 3.2-billion-year-old shallow-marine siliciclastic deposits. Nature 463:934-938

Jonkers HM, Ludwig R, De Wit R, Pringault O, Muyzer G, Niemann H, Finke N, De Beer D (2003) Structural and functional analysis of a microbial mat ecosystem from a unique permanent hypersaline inland lake: 'La Salada de Chiprana' (NE Spain). FEMS Microbiol Ecol 44:175-189

Jørgensen BB, Yehuda C, Revsbech NP (1986) Transition from anoxygenic to oxygenic photosynthesis in a microcoleus chthonoplastes cyanobacterial Mat. Appl Environ Microbiol $51: 408-417$

Kappler A, Pasquero C, Konhauser KO, Newman DK (2005) Deposition of banded iron formations by anoxygenic phototrophic Fe(II)-oxidizing bacteria. Geology 33:865-868

Kasting JF, Eggler DH, Raeburn SP (1993) Mantle redox evolution and the oxidation state of the Archean atmosphere. J Geol 101:245-257

Kazmierczak J, Altermann W (2002) Neoarchean biomineralization by benthic cyanobacteria. Science 298:2351

Konhauser KO, Newman DK, Kappler A (2005) The potential significance of microbial $\mathrm{Fe}$ (III) reduction during deposition of Precambrian banded iron formations. Geobiology 3:167-177

Kopp RE, Kirschvink JL, Hilburn IA, Nash CZ (2005) The Paleoproterozoic snowball Earth: a climate disaster triggered by the evolution of oxygenic photosynthesis. Proc Natl Acad Sci U S A 102:11131-11136

Kremer B (2006) Mat-forming coccoid cyanobacteria from early Silurian marine deposits of Sudetes, Poland. Acta Palaeontol Pol 51:143-154

Kremer B, Kazmierczak J (2005) Cyanobacterial mats from silurian black radiolarian cherts: phototrophic life at the edge of darkness? J Sediment Res 75:897-906

Kump LR (2008) The rise of atmospheric oxygen. Nature 451:277-278

Lanier WP, Lowe DR (1982) Sedimentology of the Middle Marker (3.4 Ga), Onverwacht Group, Transvaal, South Africa. Precambrian Res 18:237-260

Lowe DR, Knauth LP (1977) Sedimentology of the onverwacht group (3.4 billion years), Transvaal, south Africa, and its bearing on the characteristics and evolution of the early earth. J Geol 85:699-723 
Ludwig R, Al-Horani F, de Beer D, Jonkers HM (2005) Photosynthesis-controlled calcification in a hypersaline microbial mat. Limnol Oceanogr 50:1836-1843

Ludwig R, Pringault O, de Wit R, de Beer D, Jonkers HM (2006) Limitation of oxygenic photosynthesis and oxygen consumption by phosphate and organic nitrogen in a hypersaline microbial mat: a microsensor study. FEMS Microbiol Ecol 57:9-17

Mrozowski S (1988a) ESR studies of carbonization and coalification processes part I: carbonaceous compounds. Carbon 26:521-529

Mrozowski S (1988b) ESR studies of carbonization and coalification processes part II: biological materials. Carbon 26:531-541

Nisbet EG, Grassineau NV, Howe CJ, Abell PI, Regelous M, Nisbet RER (2007) The age of Rubisco: the evolution of oxygenic photosynthesis. Geobiology 5:311-335

Oberlin A (1989) High Resolution TEM studies of carbonization and graphitization. In: Thrower PA (ed) Chemistry and Physics of Carbon. Marcel Dekker, New York, pp 1-143 Oberlin A, Villey M, Combaz A (1978) Pyrolysis mechanism as studied by Electron Microscopy, DTA, IR and ESR. Carbon 16:73-74

Ohmoto H (1997) When did the Earth's atmosphere become oxic? Geochem News 93:26-27 Ohmoto H, Watanabe Y, Ikemi H, Poulson SR, Taylor BE (2006) Sulphur isotope evidence for an oxic Archean atmosphere. Nature 442:908-911

Ohmoto H, Runnegar B, Kump LR, Fogel ML, Kamber B, Anbar AD, Knauth PL, Lowe DR, Sumner DY, Watanabe Y (2008) Biosignatures in ancient rocks: a summary of discussions at a field workshop on biosignatures in ancient rocks. Astrobiology 8:883-1008

Olson JM (2006) Photosynthesis in the Archean Era. Photosynth Res 88:109-117

Pavlov AA, Kasting JF (2002) Mass-independent fractionation of sulfur isotopes in Archean sediments: strong evidence for an anoxic Archean atmosphere. Astrobiology 2:27-41

Perry EC Jr, Monster J, Reimer T (1971) Sulfur isotopes in Swaziland system barites and the evolution of the Earth's atmosphere. Science 171:1015-1016

Pierson BK, Castenholz RW (1974) A phototrophic gliding filamentous bacterium of hot springs, Chloroflexus aurantiacus, gen. and sp. nov. Arch Microbiol 100:5-24

Pierson BK, Castenholz RW (1995) Taxonomy and physiology of filamentous anoxygenic phototrophs. In: Blankenship RE, Madigan MT, Bauer CE (eds) Anoxygenic Photosynthetic Bacteria. Kluwer Academic Publishers, Dordrecht, pp 31-47

Pierson BK, Valdez D, Larsen M, Morgan E, Mack EE (1994) Chloroflexus-like organisms from marine and hypersaline environments: distribution and diversity. Photosynth Res 41:3552

Rasmussen B, Buick R (1999) Redox state of the Archean atmosphere: evidence from detrital heavy minerals in ca. 3250-2750 Ma sandstones from the Pilbara Craton. Aust Geol 27:115118 
Retcofsky HL, Stark JM, Friedel RA (1968) Electron spin resonance in American coals. Anal Chem 40:1699-1704

Retcofsky HL, Thompson GP, Raymond R, Friedel RA (1975) Studies of ESR linewidths in coals and related materials. Fuel 54:126-128

Reysenbach A-L, Cady SL (2001) Microbiology of ancient and modern hydrothermal systems. Trends Microbiol 9:79-86

Rosing MT, Frei R (2004) U-rich Archean sea-floor sediments from Greenland: indications of 3700 Ma oxygenic photosynthesis. Earth Planet Sci Lett 217:237-244

Rouzaud JN, Clinard C (2002) Quantitative high-resolution transmission electron microscopy: a promising tool for carbon materials characterization. Fuel Process Technol 77-78:229-235

Rouzaud JN, Guechchati N, Kister J, Conard J (1991) Structural Characterization of coalification: example of Gironville borehole. Bull Soc Géol Fr 162:201-209

Rye R, Holland HD (1998) Paleosols and the evolution of atmospheric oxygen: a critical review. Am J Sci 298:621-672

Schopf JW (2011) The paleobiological record of photosynthesis. Photosynth Res 107:87-101

Schopf JW, Hayes JM, Walter MR (1983) Evolution of Earth's Earliest Ecosystems: Recent Progress and Unsolved Problems. In: Schopf JW (ed) Earth's Earliest Biosphere. Princeton Univ. Press, Princeton, pp 361-384

Shen Y, Farquhar J, Masterson A, Kaufman AJ, Buick R (2009) Evaluating the role of microbial sulfate reduction in the early Archean using quadruple isotope systematics. Earth Planet Sci Lett 279:383-391

Skrzypczak-Bonduelle A, Binet L, Delpoux O, Vezin H, Derenne S, Robert F, Gourier D (2008) EPR of radicals in primitive organic matter: a tool for the search of biosignatures of the most ancient traces of life. App Magn Reson 33:371-397

Thomazo C, Ader M, Philippot P (2011) Extreme ${ }^{15} \mathrm{~N}$-enrichments in 2.72-Gyr-old sediments: evidence for a turning point in the nitrogen cycle. Geobiology 9:107-120

Tice MM, Lowe DR (2004) Photosynthetic microbial mats in the 3,416-Myr-old ocean. Nature 431:549-552

Towe KM (1996) Environmental oxygen conditions during the origin and early evolution of life. Adv Space Res 18:7-15

Uebersfeld J, Erb E (1956) A new effect of oxygen on the paramagnetic resonance of charcoal. CR Acad Sci Paris 243:363-364

Ueno Y, Ono S, Rumbled D, Maruyama S (2008) Quadruple sulfur isotope analysis of ca. $3.5 \mathrm{Ga}$ dresser formation: new evidence for microbial sulfate reduction in the Early Archean. Geochim Cosmochim Acta 72:5675-5691 
Vidondo B, Martinez B, Montes C, Guerrero MC (1993) Physico-chemical characteristics of a permanent Spanish hypersaline lake: 'La Salada de Chiprana' (NE Spain). Hydrobiologia 267:113-125

Villey M, Estrade-Szwarckopf H, Conard J (1981) Thermal simulation of the diagenetic evolution of kerogens: electron paramagnetic resonance analysis. Rev IFP 36:3-16 Wang M, Jiang YY, Kim KM, Qu G, Ji HF, Mittenthal JE, Zhang HY, Caetano-Anollés G (2011) A universal molecular clock of protein folds and its power in tracing the early history of aerobic metabolism and planet oxygenation. Mol Biol Evol 28:567-582

Westall F (2011) Early Life: nature, distribution and evolution. In: Gargaud M, López-Garcìa P, Martin H (eds) Origins and Evolution of Life: An Astrobiological Perspective. Cambridge University Press, Cambridge, pp 391-413

Westall F, De Ronde CEJ, Southam G, Grassineau N, Colas M, Cockell C, Lammer H (2006a) Implications of a 3.472-3.333Gyr-old subaerial microbial mat from the Barberton greenstone belt, South Africa for the UV environmental conditions on the early Earth. Philos Trans R Soc B 361:1857-1876

Westall F, De Vries ST, Nijman W, Rouchon V, Oberger B, Pearson V, Watson J, Verchovsky A, Wright I, Rouzaud JN, Marchesini D, Severine A (2006b) The 3.466 Ga "Kitty's Gap Chert", an early Archean microbial ecosystem. Geol Soc Am 405:105-131 Westall F, Cavalazzi B, Lemelle L, Marrocchi Y, Rouzaud JN, Simionovici A, Salomé M, Mostefaoui S, Andreazza C, Foucher F, Toporski J, Jauss A, Thiel V, Southam G, MacLean L, Wirick S, Hofmann A, Meibom A, Robert F, Défarge C (2011) Implications of in situ calcification for photosynthesis in a $3.3 \mathrm{Ga}$-old microbial biofilm from the Barberton greenstone belt, South Africa. Earth Planet Sci Lett 310:468-479 